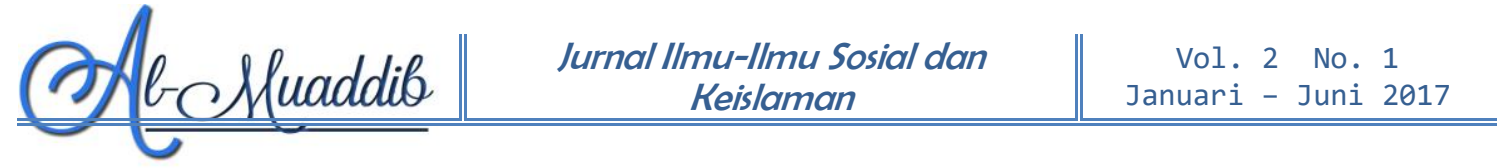

\title{
Implikasi Kebebasan Pers Terhadap Dinamika Politik Islam di Sumatera Utara Pada Masa Reformasi Periode 1998-2011
}

\author{
Nirwansyah Putra \\ Mahasiswa Pascasarjana Universitas Islam Negeri Sumatera Utara \\ Program Studi Komunikasi Islam \\ nirwan.pdj@gmail.com
}

\begin{abstract}
Post-reform period, press is not facing the power only, but also capital-media owner and professionalism itself. This impacted political Islam dynamics in North Sumatra, directly or indirectly. Islamic political discourse in the media during 1998-2011 period, inseparable with the political Islam depoliticization in the past as well as the power and economy pragmatism, also determines the general islamic discourse and weakening the potential political power of Islam. The absence of Islamic political media and structured-systematic special programs in Islamic journalism and the existence of media that are generally common-secular segmented, causing the agenda and the political Islam discourse depends on owner ideological considerations, market segmentation and policy of secular media.
\end{abstract}

\section{Kata Kunci: Kebebasan pers, kebijakan media, kapitalisasi, industrialisasi, sekularisme, politik Islam}

\section{A. Pendahuluan}

Media merupakan panggung di mana makna yang berbeda dari pemerintah-media-masyarakat, bertemu. Salah satu topiknya adalah "politik Islam". Indonesia, sebagai sebuah negara yang punya riwayat cukup dalam dan lama dengan pergulatan politik Islam, sudah lama ditengarai mempunyai kekuatan Islam secara potensial. Baik dari komposisi penduduk yang menempatkan Indonesia sebagai negara dengan jumlah umat Islam terbesar di dunia, hingga pada adanya beberapa ramalan mengenai revivalisme Islam di dunia ${ }^{1}$ yang di

${ }^{1}$ Di antaranya disebutkan oleh John L. Esposito, Islam: The Straight Path (New York: Oxford University Press, 1988), walau dia hanya meneliti kebangkitan dan pergerakan reformasi di lima negara Islam: Mesir, Libya, Iran, Libanon, dan Arab Saudi. 
antaranya bakal terjadi di Indonesia. Tentu, politik Islam tidak hanya menjadi sekedar konsep kajian semata, melainkan telah menjelma menjadi sebuah realitas objektif di Indonesia.

Di Indonesia, politik Islam tidak hanya ditunjukkan oleh hubungannya dengan negara, melainkan juga kaitannya dengan agama lain dalam kerangka relasi mayoritas-minoritas, internal-relationship dengan berbagai organisasi keislaman dan seterusnya. Media massa merekam pergulatan itu dengan berbagai kacamatanya.

Relasi antara Islam-Negara-Media ini menjadi begitu penting karena dinamika ketiganya sama-sama punya pengaruh yang cukup besar terhadap eksistensi Indonesia saat ini. Media massa sebagai salah satu instrumen sosial masyarakat, paling tidak merupakan salah satu wadah perjuangan tidak hanya oleh para aktifis Islam namun juga rangkaian ideolog, kaum intelektual dan cendekiawan Islam. Media massa telah menjadi saksi sekaligus penulis sejarah bagi pergulatan politik Islam di Indonesia.

Periodeisasi sejarah dalam kurun 1945-1949, 1950-1959, 19591966, 1966-1998 dan pasca 1998, ternyata memberikan gambaran kalau pergolakan politik Islam mengalami dinamisasi yang tidak sederhana. Adalah menarik untuk melihat bagaimanakah pola trihubungan antara negara-media massa-Islam itu: positif, negatif (konflik) ataukah malah ketiganya terpisahkan dan tak berhubungan sama sekali. Pertanyaan-pertanyaan, misalnya bagaimana media massa menggambarkan dinamika politik Islam dan negara, sebagai contoh, menjadi suatu hal yang menarik untuk ditelusuri. Ataukah malah terjadi hubungan mutual ataupun interdependensi antara media massa-politik Islam dan karena itu pula menjadi hubungan kontradiktif dengan negara? Kajian ini merumuskan tiga pertanyaan cukup mendasar. ${ }^{2}$

${ }^{2}$ Apa dan bagaimanakah implikasi kebebasan pers terhadap dan dinamika politik Islam di Sumatera Utara pada masa reformasi periode 1998-2011. Apa dan bagaimana klasifikasi definisi dan pemaknaan soal politik Islam dalam kurun waktu 


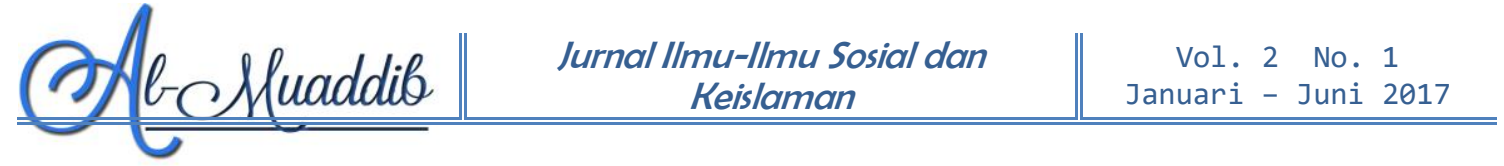

\section{B. Pendekatan Kajian}

Kajian ini menggunakan pendekatan kualitatif dengan model deskriptif. Melalui pendekatan ini, diharapkan dapat secara mendalam dan komprehensif membahas, menggambarkan, mengklasifikasikan serta menarik beberapa kesimpulan untuk menjawab pertanyaanpertanyaan penelitian. Data kualitatif, seperti dikatakan Miles dan Huberman (1992) juga lebih condong dapat membimbing peneliti untuk memperoleh penemuan-penemuan yang tak diduga sebelumnya dan untuk membentuk kerangka teoritis baru, sehingga membantu peneliti untuk melangkah lebih jauh dari praduga dan kerangka kerja awal. ${ }^{3}$

Untuk melakukan analisis dan interpretasi kualitatif maka dipakai pendekatan historis-komparatif4 dan pendekatan ekonomipolitik. Untuk itu, mula-mula penulis berharap dapat mengungkap rincian historis masalah ini dan kemudian menafsirkannya dalam kerangka teori yang digunakan dalam studi ini. Merangkainya dengan pendekatan ekonomi-politik dalam melihat perjalanan media massa di Indonesia, khususnya di Sumatera Utara, menjadikan kajian ini mengarah pada analisis komparatif terhadap gagasan dan praktik para pemilik dan pekerja di media massa, intelektual dan politisi muslim dari beberapa generasi yang berbeda, dan mengkomparasinya dengan kebijakan negara yang juga diambil dalam suatu masa di mana kekuatan sosial politik ekonominya juga berbeda-beda pula.

tertentu yang dimaksudkan oleh redaksi media massa sekaligus mendeskripsikan landasan nilai-nilai filosofis dan perjuangan media yang bersangkutan dalam persoalan Politik Islam di Sumatera Utara. Apa dan bagaimana dampak kebijakan ideologis media massa soal politik Islam dalam proses penggarapan pemberitaan dan produk jurnalistik yang dihasilkan?

${ }^{3}$ Matthew B. Miles, dan A. Michael Huberman, Analisis Data Kualitatif: Buku Sumber Tentang Metode-metode Baru (Jakarta: UI Press, 1992), h. 1-2.

${ }^{4}$ Pendekatan historis komparatif ini dalam kerangka bahwa peristiwa yang terjadi belakangan dapat ditengarai sebagai satu rangkaian yang tak pula dapat dipisahkan begitu saja. 


\section{Media, Negara dan Masyarakat}

\section{Kekuasaan, Organisasi, Sasaran dan Kedudukan Media}

Antonio Gramsci melihat media sebagai sebuah ruang di mana berbagai ideologi direpresentasikan ${ }^{5}$. Di satu sisi media bisa menjadi sarana penyebaran ideologi penguasa, alat legitimasi dan kontrol atas wacana publik. Namun di sisi lain, media bisa menjadi alat resistensi terhadap kekuasaan (ideological state apparatus). Kesimpulannya adalah media massa bukan sesuatu yang bebas, independen, tetapi memiliki keterkaitan dengan realitas sosial karena berbagai kepentingan yang bermain dalam media massa. Dalam media massa juga terselubung kepentingan yang lain, misalnya kepentingan kapitalisme pemilik modal, sustainabilitas lapangan kerja bagi para karyawan dan sebagainya. Dalam kondisi dan posisi seperti ini, media massa tidak mungkin berdiri statis di tengah-tengah, dia akan bergerak dinamis di antara kepentingan-kepentingan. Di antara gagasan Marxis yang begitu kompleks soal media, telah mendorong lahirnya teori politik-ekonomi ${ }^{6}$, teori $\mathrm{kritik}^{7}$, dan teori hegemoni media ${ }^{8}$.

Di sisi lain, dalam penelitiannya tentang wartawan surat kabar sejak 1965 di Inggris, Jeremy Tunstall (1971) telah mengemukakan sasaran surat kabar dengan menggunakan istilah ekonomi: sasaranberpendapatan (revenue goal) dan tidak-berpendapatan (non-revenue

${ }^{5}$ Eriyanto. Analisis Wacana, Pengantar Analisis Teks Media. (Yogyakarta: LkiS, 2005), h. 67.

${ }^{6}$ Lihat Smythe, D.W. "Communications: Blindspot of Western Marxism," dalam Canadian Journal of Political and Social Theory (1977) 1:120-7, dalam Denis McQuail, Teori Komunikasi Massa, Suatu Pengantar (Jakarta: Erlangga, Edisi Kedua, 1991). h. 64

${ }^{7}$ Denis McQuail, Teori Komunikasi Massa, Suatu Pengantar (Jakarta: Erlangga, Edisi Kedua, 1991), h. 65.

${ }^{8}$ Antonio Gramsci, "Quaderni del carcere," dalam Quentin Hoare dan Geoffrey Nowell Smith (ed). Selection from the Prison Notebooks (London: ElecBook, 1999), versi online: http:// courses.justice.eku.edu/pls330_louis/docs/gramsci-prison-notebooksvol1.pdf, diakses 2 September 2016. Versi online dari buku ini sebagai pembanding juga dapat dilihat https://www.marxists.org/archive/gramsci/prison_notebooks/selections.htm, diakses 2 September 2016. Lihat juga karya L. Althusser, Ideology and Ideological State Apparatuses, in Lenin and Philosophy and Other Esaays. (London: New Left Books, 1971) dalam h. 66. 
goal). ${ }^{9}$ Pengorganisasian media yang terikat pada kebijakan politik negara dan partai politik, juga bervariasi. Penelitian Mary Catherine French (2014)10 tentang jurnalisme di Soviet kurun 1955-1966, mengungkapkan hal-hal menarik soal pengorganisasian media resmi Liga Pemuda Komunis atau Komsomol bernama Komsomol'skaia Pravda (KP). Patut disimak pula penelitian yang dilakukan tiga peneliti World Bank yaitu Simeon Djankov, Caralee McLiesh, Tatiana Nenova, dan Andrei Shleifer dari Harvard University, terhadap 97 negara yang kemudian diterbitkan dalam artikel berjudul Who Owns the Media? (2003) ${ }^{11}$, mendapatkan hasil kalau secara umum media-media besar dimiliki oleh pemerintah dan grup keluarga tertentu.

\section{Industrialisasi dan Kapitalisasi Media}

Pada 2014, laporan WAN menyatakan pendapatan media surat kabar (cetak) di seluruh dunia sepanjang 2013 mencapai US\$163 Miliar. Sirkulasi suratkabar setiap harinya mencapai 534 juta eksemplar naik 2\% dari 2012. Pembaca media cetak sekitar 2,5 juta orang dewasa, sementara pembaca digital mencapai 800 juta pengguna internet (melesat 23\% dari 2012). Pendapatan media digital mencapai US $\$ 1,7$ miliar atau melonjak $60 \%$ dari 2012. Sementara pendapatan iklan digital mencapai US\$8,5 miliar (naik 11\% dari 2012) ${ }^{12}$.

Jika dikaitkan dengan penelitian ini yang membatasi periode waktu 1998-2011, maka data-data di atas menunjukkan, pada pasca era reformasi di Indonesia, kecenderungan industri pers di dunia sedang mengalami tren kenaikan. Pada 1991 ketika populasi hampir mencapai 190 juta, tingkat penjualan nasional untuk penerbitan pers (surat kabar dan majalah) di

9Jeremy Tunstall, Journalist at Work. (London: Constable, 1971). h. 51

10Lihat Mary Catherine French, Reporting Socialism: Soviet Journalism and the Journalists' Union, 1955-1966. Publicly Accessible Penn Dissertations (Pennsylvania: Penn Libraries University Pennsylvania, 2014), h. 102. Versi online diakses di http:// repository.upenn.edu/cgi/viewcontent.cgi? article=3089\&context=edissertations pada 3 September 2016.

11Simeon Djankov, et. al., "Who Owns the Media?," Journal of Law and Economics, vol. XLVI (University of Chicago, 2003), h. 341-381 6.

${ }^{12}$ Mira Milosevic, et. al., World Press Trends 2014 (Paris: WAN-IFRA, 2014). h. 
Indonesia seluruhnya mencapai hanya sedikit di atas 13 juta eksemplar. ${ }^{13}$ Fenomena lain adalah tumbuhnya pemberitaan-pemberitaan pers yang bersimpati pada oposisi, diikuti dengan masuknya pemilik modal kelas berat ke dalam industri ini di akhir periode 1980-an. Hingga 2016, media-media di Indonesia telah terkonsentrasi pada grup-grup besar pemilik modal, dengan diversifikasi usaha media yang merambah ke seluruh jenis media. Grup-grup besar media itu tergambar dalam gambar di bawah ini.

\section{Gambar 1. Grup Media Terbesar di Indonesia 2016}

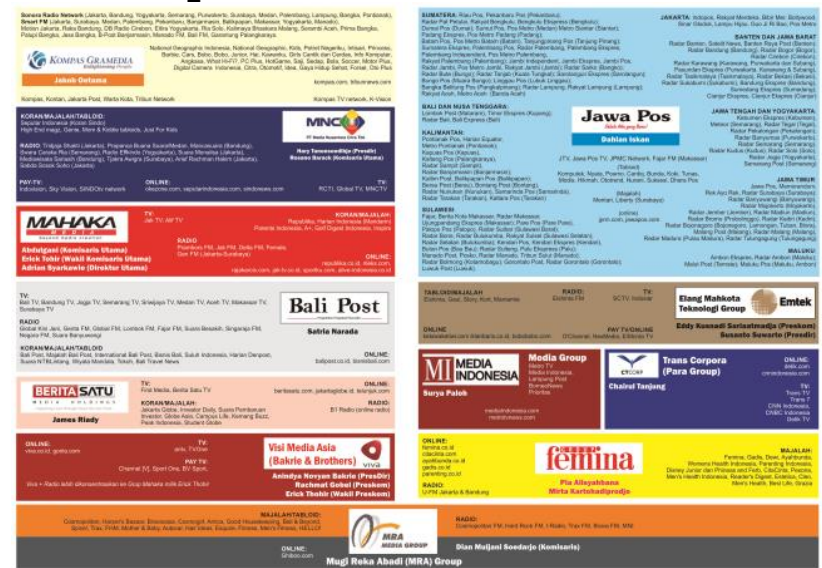

Sumber: Diramu dari berbagai sumber, Merlyna Lim ${ }^{14}$, Ignatius Haryanto ${ }^{15}$, wikipedia.org, indonesia-investments.com, dan sumber-sumber lain.

Lihat pula pendapatan iklan media di Indonesia seperti tertera di bawah ini:

${ }^{13}$ David T. Hill, Pers di Masa Orde Baru (Jakarta: Yayasan Pustaka Obor Indonesia, 2011), h. 10.

${ }^{14}$ Merlyna Lim, The League of Thirteen: Media Concentration in Indonesia (Arizona: Participatory Media Lab Arizona State University, 2012), h. 3, sumber: http://www.public.asu.edu/ mlim4/files/Lim_IndoMediaOwnership_2012.pdf diakses 10 Maret 2013.

15Ignatius Haryanto, "Media Ownership and Its Implication for Journalists and Journalism in Indonesia," dalam Krishna Sen and David Hill (eds.), Politics and the New Media in 21st Century Indonesia: Decade of Democracy (New York: Routledge, 2011). h. 104. 


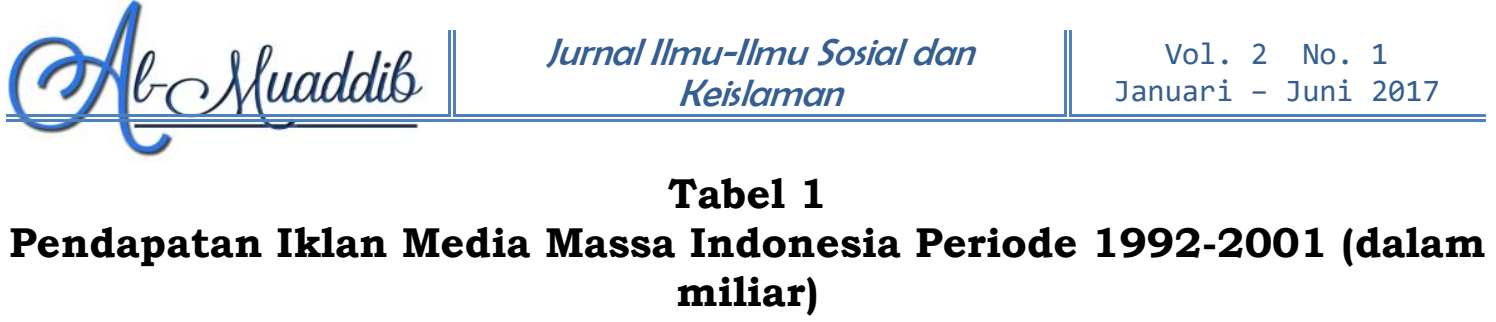

\begin{tabular}{|c|c|c|c|c|c|c|c|}
\hline \multirow[b]{2}{*}{ TAHUN } & \multicolumn{6}{|c|}{ MEDIA } & \multirow[b]{2}{*}{ TOTAL } \\
\hline & MAJALAH & TABLOID & $\begin{array}{l}\text { SURAT } \\
\text { KABAR }\end{array}$ & RADIO & TV & OUTDOOR & \\
\hline 1998 & $\begin{array}{l}133 \\
(3,5)\end{array}$ & $\begin{array}{l}58 \\
(1,5)\end{array}$ & $\begin{array}{l}956 \\
(25,4)\end{array}$ & $\begin{array}{l}136 \\
(3,6)\end{array}$ & $\begin{array}{l}2.212 \\
(58,8)\end{array}$ & $\begin{array}{l}261 \\
(6,9) \\
\end{array}$ & 3.756 \\
\hline 1999 & $\begin{array}{l}194 \\
(3,4)\end{array}$ & $\begin{array}{l}98 \\
(1,7) \\
\end{array}$ & $\begin{array}{l}1.415 \\
(25,2)\end{array}$ & $\begin{array}{l}187 \\
(3,3)\end{array}$ & $\begin{array}{l}3.449 \\
(61,4)\end{array}$ & $\begin{array}{l}269 \\
(4,7) \\
\end{array}$ & 5.612 \\
\hline 2000 & $\begin{array}{l}266 \\
(4,2) \\
\end{array}$ & \begin{tabular}{|l|}
133 \\
$(2,1)$ \\
\end{tabular} & $\begin{array}{l}1.803 \\
(28,6)\end{array}$ & $\begin{array}{l}215 \\
(3,4)\end{array}$ & $\begin{array}{l}4.201 \\
(66,7)\end{array}$ & \begin{tabular}{|l|}
309 \\
$(4,9)$ \\
\end{tabular} & 6.297 \\
\hline 2001 & - & - & - & - & - & - & 9.006 \\
\hline 2002 & - & - & - & - & - & - & - \\
\hline 2003 & - & - & - & - & - & - & - \\
\hline 2004 & - & - & - & - & - & - & - \\
\hline 2005 & $\begin{array}{l}890 \\
(3,2)\end{array}$ & $\begin{array}{l}398 \\
(1,4)\end{array}$ & $\begin{array}{l}7.498 \\
(26,9)\end{array}$ & $\begin{array}{l}537 \\
(1,9)\end{array}$ & $\begin{array}{l}17.756 \\
(63,7)\end{array}$ & $\begin{array}{l}790 \\
(2,8)\end{array}$ & 27.869 \\
\hline 2006 & $\begin{array}{l}920 \\
(2,8)\end{array}$ & $\begin{array}{l}402 \\
(1,2)\end{array}$ & $\begin{array}{l}8.995 \\
(27,9)\end{array}$ & $\begin{array}{l}527 \\
(1,6)\end{array}$ & $\begin{array}{l}20.623 \\
(63,9)\end{array}$ & $\begin{array}{l}827 \\
(2,6)\end{array}$ & 32.294 \\
\hline 2007 & $\begin{array}{l}1,010 \\
(2,7)\end{array}$ & \begin{tabular}{|l|}
446 \\
$(1,2)$
\end{tabular} & $\begin{array}{l}11.759 \\
(31.2) \\
\end{array}$ & $\begin{array}{l}535 \\
(1,4) \\
\end{array}$ & $\begin{array}{l}23.073 \\
(61,3) \\
\end{array}$ & \begin{tabular}{|l|}
845 \\
$(2,2)$ \\
\end{tabular} & 37.668 \\
\hline 2008 & $\begin{array}{l}1,223 \\
(2,7)\end{array}$ & $\begin{array}{l}562 \\
(1,3)\end{array}$ & $\begin{array}{l}15.032 \\
(33,8)\end{array}$ & $\begin{array}{l}559 \\
(1,3)\end{array}$ & $\begin{array}{l}26.241 \\
(59)\end{array}$ & \begin{tabular}{|l|}
875 \\
$(2)$
\end{tabular} & 44.491 \\
\hline 2009 & $\begin{array}{l}1,292 \\
(2,5)\end{array}$ & $\begin{array}{l}609 \\
(1,2) \\
\end{array}$ & $\begin{array}{l}17.747 \\
(34,7) \\
\end{array}$ & $\begin{array}{l}593 \\
(1,2) \\
\end{array}$ & $\begin{array}{l}29.887 \\
(58,5) \\
\end{array}$ & $\begin{array}{l}954 \\
(1,9) \\
\end{array}$ & 51.081 \\
\hline 2010 & $\begin{array}{l}1,371 \\
(2,3)\end{array}$ & $\begin{array}{l}670 \\
(1,1) \\
\end{array}$ & $\begin{array}{l}20.409 \\
(34,9)\end{array}$ & $\begin{array}{l}622 \\
(1,1)\end{array}$ & $\begin{array}{l}34.370 \\
(58,8)\end{array}$ & $\begin{array}{l}1,040 \\
(1,8)\end{array}$ & 58.481 \\
\hline
\end{tabular}

sumber: AC-NIELSEN-AEM, Lowe Lintas \& Partners, Media Scene, AJI ${ }^{16}$

Terlihat peningkatan jumlah belanja iklan yang sangat signifikan dari tahun ke tahun. Kenaikan ini jelas didorong oleh massifnya periklanan di televisi swasta. Bila di tahun 1998 hanya Rp3,75 triliun, menjadi Rp58,4 triliun (2010), atau lebih 19 kali lipat dalam waktu 12 tahun saja, jelas bukan sebuah angka yang murah.

Dari tabel di atas dapat dilihat kenyataan lain. Pesaing terbesar televisi yaitu surat kabar yang mencapai angka tertinggi pada 2010 yaitu 34,9\% (Rp20,4 triliun). Bila diperhatikan mulai 1992, maka persentase itu terus mengalami penurunan dari $34,5 \%$ menjadi $28,6 \%$

16 Disadur dari Ishadi SK, Media dan Kekuasaan; Televisi di Hari-hari Terakhir Presiden Soeharto (Jakarta: Penerbit Buku Kompas, 2014). h. 78; dan Abdul Manan, Ancaman itu Datang dari Dalam: Laporan Tahunan Aliansi Jurnalis Independen 2010 (Jakarta: Aliansi Jurnalis Independen, 2010), h.32, Tabel 3.1. 
pada 2000. Namun, angka itu menaik lagi setelah pada 2005 (26,9\%) dan mencapai angka tertinggi pada 2010 yaitu 34,9\%. Anjloknya perekonomian Indonesia pada 1997-1998 jelas menjadi faktor utama dari turunnya pendapatan iklan surat kabar sebesar 4,8\% seiring dengan anjloknya pendapatan seluruh media dari Rp5,08 triliun pada 1997 menjadi Rp3,7 triliun (1998) atau 26,1\%. Dari periode 2005-2010, bila rata-rata seluruh media (televisi, radio, majalah, tabloid, outdoor) mengalami tren penurunan pendapatan dari iklan nasional, hal demikian justru sebaliknya terjadi pada surat kabar.

Krisis moneter yang menerpa Indonesia kurun 1997-1998 memang membuat harga-harga mengalami kenaikan yang cukup tinggi sementara daya beli merosot tajam. Pada Oktober 2000, dilaporkan Serikat Penerbit Suratkabar (SPS) mengeluhkan kenaikan harga kertas koran yang ditetapkan oleh PT Aspek Paper per 1 Oktober yang mencapai 10,34\% dari 580 dolar AS per metrik ton (MT) menjadi 640 dolar per MT. SPS waktu itu meminta kenaikan paling tinggi yang bisa ditoleransi hanya maksimal 630 Dolar AS per MT. ${ }^{17}$

Ambruknya perekonomian yang berakibat langsung pada penurunan iklan, tentu saja berbanding lurus dengan bangkrutnya sejumlah media yang begitu banyak tumbuh sejak era 1998. Walau, faktor finansial ini bukan satu-satunya penyebab untuk itu.

\section{Kebebasan Media}

Perserikatan Bangsa-Bangsa (PBB) sendiri telah menyatakan soal kebebasan mengemukakan pendapat dalam article 19 Universal Declaration of Human Rights tahun 1948:

"Everyone has the right to freedom of opinion and expression; this right includes freedom to hold opinions without interference and to seek, receive and impart information and ideas through any media and regardless of frontiers." 18

\footnotetext{
2016.

${ }^{17} \mathrm{http}: / /$ arsip.gatra.com/2000-10-10/artikel.php?id=152 diakses 28 Oktober

${ }^{18}$ Sumber

http://www.un.org/en/universal-declaration-humanrights/index. $h$ tml diakses 5 September 2016.
} 
Selain PBB, beberapa lembaga dunia ${ }^{19}$ juga mengukur indeks kebebasan pers di dunia. Dalam pada itu, implikasi westernisasi, khususnya Amerika, yang mendominasi melalui media internasional, telah menjadi kajian tersendiri. Sejak UNESCO mensponsori studi bisnis media pada 197420, terlihat bahwa telah terjadi produksi kultural yang bersifat satu arah (one-way flow) dari negara maju ke negara berkembang, Fenomena ini juga menimbulkan berkembangnya "pendekatan imperialisme media" yang mendominasi analisis perkembangan media internasional melalui tahun 1970-an. ${ }^{21}$ Bahwa, kendali korporasi besar terhadap kekuasaan negara dan sebaliknya, justru menjadikan media massa hanyalah alat kekuasaan. Mohammad Amien Rais, misalnya, menganggap media massa utama di Amerika Serikat yang telah menjadi alat pembentuk opini publik, telah menjadi alat kepentingan korporasi. ${ }^{22}$

Dalam kasus Indonesia secara nasional, Jakob Oetama, menulis soal kehadiran media massa, terutama televisi, yang mulanya untuk kepentingan politik. ${ }^{23}$ Menurut Jakob, dalam pemaknaan kebebasan yang bertanggung jawab dalam orba, berbeda dengan di masa orla dan reformasi; pada era orba, dengan represi kekuasaan yang intensif dan masif, media bersinggungan erat dengan masalah media dan kekuasaan, sementara masa reformasi, media dan bisnis ekonomi versus kepentingan pemilik/pemodal.

${ }^{19} \mathrm{Di}$ antara yang mempunyai jaringan internasional adalah Reporters Without Borders (RWB), The Committee to Protect Journalists (CPJ), dan Freedom House. Ketiga organisasi ini punya kegiatan yang hampir sama walau mempunyai variasi karakteristik tersendiri dalam mengukur kebebasan pers di dunia.

${ }^{20}$ Lihat K. Nordenstreng dan T. Varis. Television Traffic - A One Way Street? (Paris: UNESCO, 1974).

${ }^{21}$ Kalyani Chadha dan Anandam Kavoori, "Media imperialism revisited: some findings from the Asian Case," dalam Media Culture \& Society (2000), h. 415-432, sumber:

https://www.researchgate.net/profile/Kalyani_Chadha/publication/240707871_Medi a_imperialism_revisited_Some_findings_from_the_Asian_case/links/5754210208ae10d 933792d39.pdf?origin=publication_detail diakses pada 5 September 2016.

${ }^{22}$ Mohammad Amien Rais, Agenda Mendesak Bangsa, Selamatkan Indonesia! (Yogyakarta: PPSK Press, 2008), h. 116.

${ }^{23}$ Ishadi SK, Media dan Kekuasaan Televisi di Hari-hari Terakhir Presiden Soeharto, (Jakarta, Penerbit Buku Kompas, 2014), h. x-xiii. 


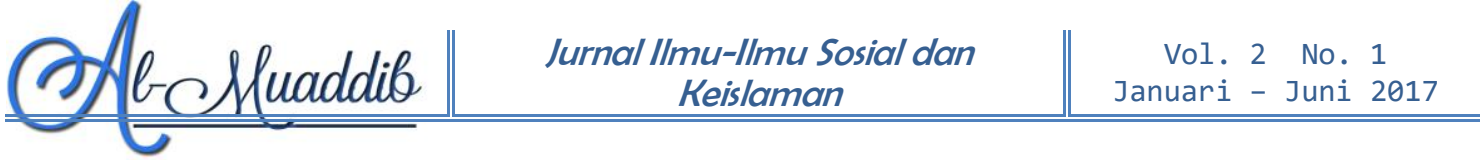

Kolaborasi antara kapitalisasi dan politik lalu terlihat pada fenomena kepemilikan media dengan afiliasi parpol seperti Viva News Group yang dimiliki oleh Aburizal Bakrie selaku petinggi Partai Golkar, MNC Group oleh Harry Tanoesoedibjo (Hanura dan kemudian mendiri parpol sendiri yaitu Partindo) Media Group yang dimiliki oleh Surya Paloh (Ketua Umum Partai Nasional Demokrat), hingga Dahlan Iskan (Grup Jawa Pos) yang pernah diangkat sebagai Menteri Badan Usaha Milik Negara (BUMN) di era Susilo Bambang Yudhoyono.

Pasca reformasi, UU Pokok Pers No. 40/1999 menempatkan kebebasan pers (UU ini memakai istilah "kemerdekaan pers") sebagai hal yang sangat penting. Di urutan pertama mengenai pertimbangan UU ini, yaitu di huruf a, dinyatakan:

"bahwa kemerdekaan pers merupakan salah satu wujud kedaulatan rakyat dan menjadi unsur yang sangat penting untuk menciptakan kehidupan bermasyarakat, berbangsa dan bernegara yang demokratis, sehingga kemerdekaan mengeluarkan pikiran dan pendapat sebagaimana tercantum dalam Pasal 28 Undang-undang Dasar 1945 harus dijamin;"

Kemudian, di Pasal 2 disebutkan: "Kemerdekaan pers adalah salah satu wujud kedaulatan rakyat yang berasaskan prinsip-prinsip demokrasi, keadilan, dan supremasi hukum."

Dalam bagian Penjelasan Pasal 4 Ayat (1) dinyatakan:

"Yang dimaksud dengan 'kemerdekaan pers dijamin sebagai hak asasi warga negara' adalah bahwa pers bebas dari tindakan pencegahan, pelarangan, dan atau penekanan agar hak masyarakat untuk memperoleh informasi terjamin. Kemerdekaan pers adalah kemerdekaan yang disertai kesadaran akan pentingnya penegakan supremasi hukum yang dilaksanakan oleh pengadilan, dan tanggung jawab profesi yang dijabarkan dalam Kode Etik Jurnalistik serta sesuai dengan hati nurani insan pers."

Namun, akan ada beragam batasan yang diberikan oleh pekerja pers terhadap istilah kebebasan pers. Pada pokoknya, kebebasan pers itu sendiri tidak memiliki makna tunggal. Dia bisa berarti bebas pada kepemilikan dan mengatur institusi pers, proses produksi karya 
jurnalistik dan penyebaran informasi, serta pengorganisasian kalangan wartawan dalam organisasi profesi. Kebebasan juga ditandai dengan sebuah variabel antara yang sangat penting yaitu kontrol kekuasaan. Kekuasaan ini tidak hanya melulu soal kekuasaan politik tapi juga merambah ke ekonomi (pasar), sosial dan kebudayaan.

\section{Gambar 2}

\section{Dimensi Kebebasan Pers}

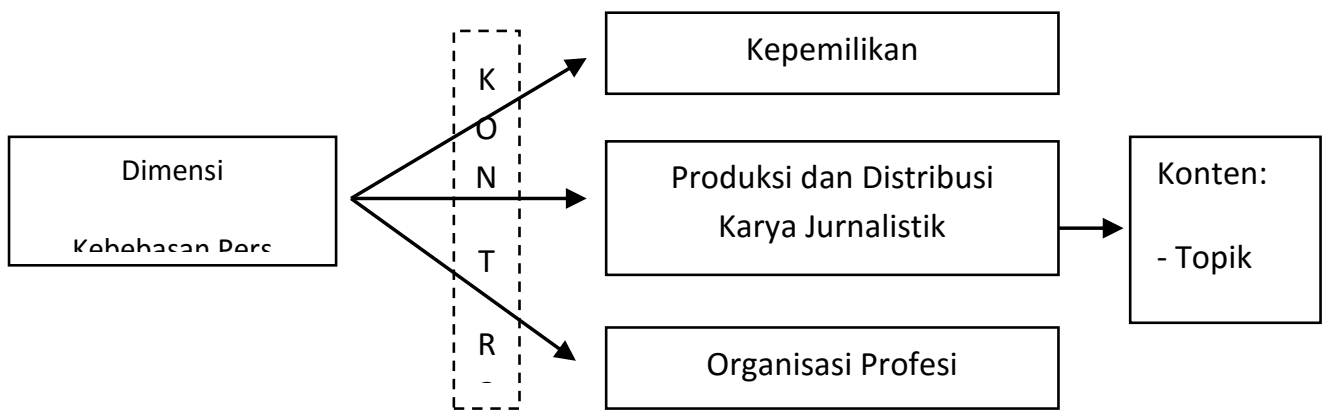

Memang, ada kesan yang muncul kalau ini menggambarkan adanya suatu komparasi antara situasi pasca terbitnya UU Pokok Pers No. 40 tahun 1999 dan orba. Ada perbandingan yang langsung vis a vis atau berhadapan, seolah-olah di masa pasca 1999 begitu kontras dengan masa orba: orba tak bebas, subordinatif dan reformasi adalah bebas, independen. Bagaimana situasi itu dikesankan begitu kontras? Variabel antara yang telah disebutkan sebelumnya yaitu kontrol kekuasaan, mengambil perannya di sini. Kontrol kekuasaan berada di tangan pemerintah dan masyarakat ataupun kolaborasi antara keduanya.

Posisi subordinasi itu justru menjadikan pers hanya sebagai corong kekuasaan yang berkonsekuensi pada dua hal sifat informasi mengenai kekuasaan:

a. Mengabaikan peristiwa yang dapat mengganggu stabilitas ataupun berdampak negatif terhadap pemerintahan.

b. Menutup peristiwa yang negatif terhadap pemerintah. Hal yang kedua ini dilakukan dengan cara: (a) Memoles berita yang negatif tersebut 


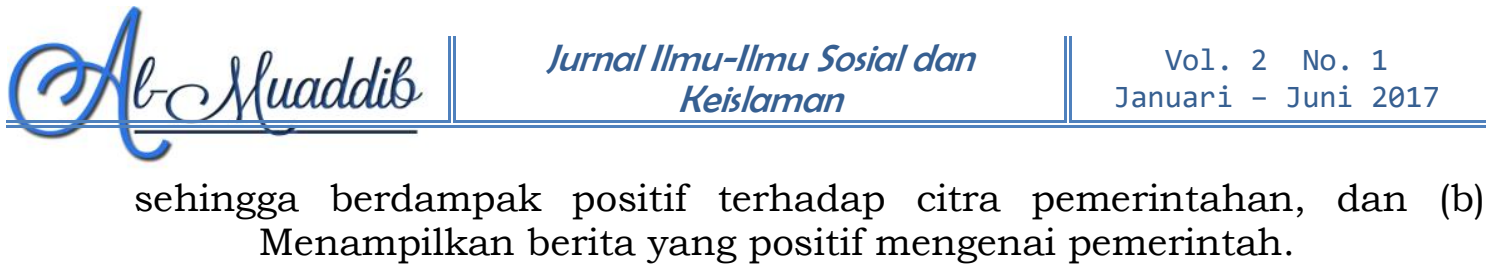

Namun, menyokong pemikiran kondisi vis a vis antara orba dan reformasi itu akan sama sekali tidak menguntungkan karena pertama, pada dasarnya kalangan media sendiri mengakui kalau di masa orba pun kebebasan bukannya tak eksis, terutama di awal orba. Bila ada ketidakbebasan dalam memberitakan kekuasaan Soeharto, keluarga dan kroninya (di skup lokal Kota Medan dan Sumut patut dicatat pula ada ketidakbebasan ketika memberitakan persoalan Organisasi Kemasyarakatan Pemuda), maka di luar itu kalangan pers aktif untuk menyoroti kritik sosial di luar itu.

Itu perspektif pertama. Perspektif kedua adalah adanya pandangan bahwa di masa reformasi dan kemudian dikeluarkannya UU Pokok Pers No. 40 tahun 1999, telah menjadi gerbang kemerdekaan pers yang sesungguhnya di Indonesia. Dari segi formal, maka bila kebebasan diukur dari tidak diberlakukannya kembali Surat Izin Usaha Penerbitan Pers (SIUPP), "lembaga telepon" dari pemerintah dan militer, dan lain-lain aturan yang mengekang pers Indonesia, memang mendapatkan justifikasinya. Namun justru di masa reformasi, perspektif kebebasan pers semakin diperluas dengan adanya persoalan di internal pers sendiri, yaitu etik pada konten informasi yang diberitakan.

\section{Islam dan Media}

\section{Perspektif Teoritis}

Menurut Bahtiar Effendy, secara garis besar, ada dua spektrum pemikiran politik Islam yang berbeda. 24 Spektrum pertama beranggapan bahwa Islam harus menjadi dasar negara; bahwa syari'ah harus diterima sebagai konstitusi negara; bahwa kedaulatan politik ada

${ }^{24}$ Bahtiar Effendy, Islam dan Negara: Transformasi Gagasan dan Praktik Politik Islam di Indonesia (Jakarta: Paramadina, 1998). h. 13. 


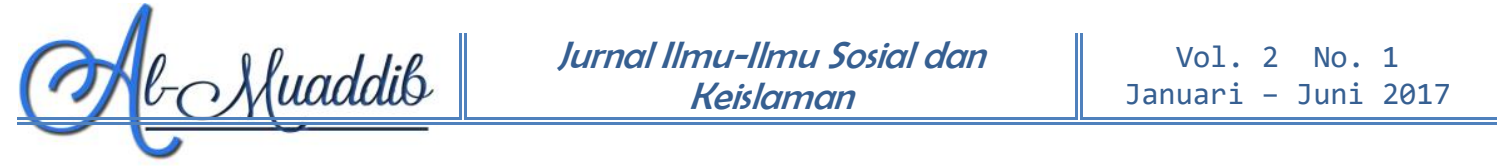

di tangan Tuhan; bahwa gagasan tentang negara-bangsa (nation-state) bertentangan dengan konsep ummah (komunitas Islam) yang tidak mengenal batas-batas politik atau kedaerahan. Sedangkan prinsip syûrâ (musyawarah) walau diakui namun aplikasi prinsip itu berbeda dengan gagasan demokrasi politik modern dewasa ini.

Pada spektrum kedua, beberapa kalangan Muslim lainnya berpendapat bahwa Islam "tidak mengemukakan suatu pola baku tentang teori negara (atau sistem politik) yang harus dijalankan oleh ummah." Menurut aliran pemikiran ini, bahkan istilah negara (dawlah) pun tidak dapat ditemukan dalam al-Qur'ân. Meskipun terdapat berbagai ungkapan dalam Alquran yang merujuk atau seolah-olah merujuk kepada kekuasaan politik dan otoritas, ungkapan-ungkapan ini hanya bersifat insidental dan tidak ada pengaruhnya bagi teori politik. Bahtiar Effendy kemudian mengajukan lima ${ }^{25}$ pendekatan untuk melihat hubungan antara Islam dan Politik yakni26.

Dalam kaitan itu, pandangan Nasikun baik pula diutarakan di sini, yaitu konflik-konflik ideologis di antara berbagai golongan di dalam masyarakat Indonesia, telah menjadi sebab bagi timbulnya kesulitan-kesulitan untuk mempertumbuhkan aturan permainan (rules of the game) di antara mereka di dalam hubungan-hubungan kekuasaan. ${ }^{27}$

\section{Keagamaan di Sumut}

Di Sumut, mobilitas keagamaan tidak bisa hanya dipahami dalam bingkai wilayah Sumut secara administratif. Al-Jami'atul Wasliyah (lahir pada 30 November 1930/ 9 Rajab 1349 H di Kota Medan) yang mendominasi penyebaran di pantai Timur, mengalami persamaan dan perbedaan tipologi dengan kawasan pantai barat, di mana pola pendidikan pesantren dan kedekatan secara kultural-

${ }^{25}$ Dekonfessionalisasi, domestikasi Islam, skismatik aliran, trikotomi dan Islam kultural

${ }^{26} \mathrm{Ibid}$, h. 22-54.

${ }^{27}$ Nasikun, Sistem Sosial Indonesia (Jakarta: Rajawali Press, 2010), h. 89-101. 


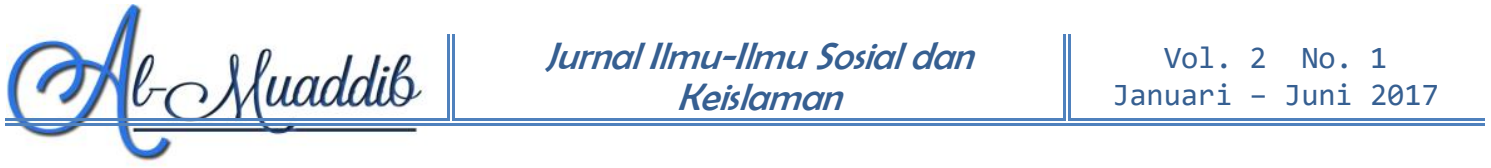

keagamaan dengan organisasi Islam Nahdhatul Ulama (NU) begitu kentara. Pada 1930, misalnya, Syeikh Musthafa Husain Purbabaru mendirikan Persatuan Muslim Tapanuli yang kemudian berafiliasi ke NU. Bersama muridnya, Syeikh Ahmad Dahlan, dia kemudian mendirikan Al-Ittihadiyah di Medan pada 1935.28

Tidak hanya itu. Organisasi Muhammadiyah yang menurut beberapa kajian sudah dimulai sejak 25 November 1927 di Kota Medan dan kemudian diresmikan pada 1 Juli 1928, juga hadir. Perantau pendakwah dari Minangkabau, Tapanuli Tengah, Jawa dan lain daerah turut memengaruhi kinerja organisasi. Bahkan, pada 22 Desember 1939, ketika H. R. Muhammad Said, Ketua Perwakilan Hofd Bestur (HB) Muhammadiyah Daerah Pesisir Timur, wafat, jabatannya untuk sementara digantikan, di antaranya oleh Hamka, yang berasal dari Sumatera Barat. 29

Tentu saja, Islam tidak sendiri di provinsi ini. Menurut Shohibul Anshor Siregar, dalam penelitiannya mengenai Sisingamangaraja XII, diinformasikan bahwa para penginjil Rheinische Missions-Gesellschaft (RMG) merupakan pihak yang pertama-tama menyebarkan tentang Islamnya Sisingamangaraja XII menjelang 1880-an. Hal itu dikaitkan dengan kerjasama Singamangaraja XII dengan Aceh, menentang para penginjil RMG yang bahu-membahu bersama kolonial Belanda. Atas permintaan penginjil RMG, terutama Ludwig Ingwer Nommensen, kolonial Belanda akhirnya menyerang markas Sisingamangaraja XII di Bakkara dan memasukkan Toba dan Silindung ke dalam wilayah jajahan Belanda. ${ }^{30}$

${ }^{28} \mathrm{Al}$ Rasyidin. Islamic Organizations in North Sumatra; The Politics of Initial Establishment and Later Development. Journal of Indonesia Islam Vol 10 No. 1 Juni 2016, h-h. 63-88, edisi online di http://jiis.uinsby.ac.id/index.php/JIIs/article/view/210/164, diakses 30 Oktober 2016.

${ }^{29}$ Wawancara dengan Shohibul Anshor Siregar, 16 September 2015.

30 ibid. 


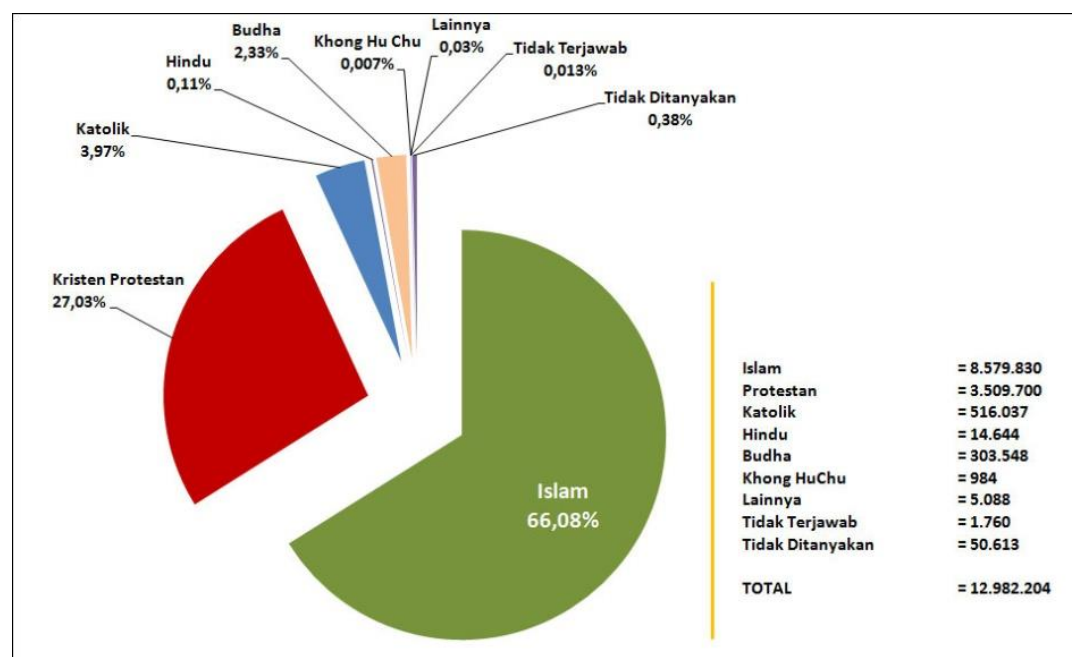

sumber: Sensus Penduduk 201031

Memang, akan ada pertanyaan besar yang menarik. Pertama, apakah gerakan politik Islam itu bertujuan untuk memperbesar jumlah pemeluk agama Islam? Kedua, ataukah gerakan politik Islam bertujuan untuk menguatkan internal umat Islam saja? Dan ketiga, apakah ada kemungkinan gerakan politik Islam justru terjadi antara internal umat Islam untuk memperbesar keanggotaan dari suatu aliran atau organisasi Islam tertentu?

\section{Islam, Politik Islam dan Media}

Term Islamophobia sebagai sebuah streotype, barangkali adalah topik yang paling sering muncul dalam melihat beragam hubungan antara politik Islam dan media, terutama di Eropa dan AS. Tidak mudah untuk menyisihkan istilah ini apalagi ketika hal-hal seperti terorisme, radikalisme hingga fundamentalisme menjadi bingkai khusus media dalam melihat Islam dan umat Islam. Tak dapat dipungkiri kalau hancurnya World Trade Center (WTC) di New York

31 Badan Pusat Statistik, Kewarganegaraan, Suku Bangsa, Agama dan Bahasa Sehari-hari Penduduk Indonesia: Hasil Sensus Penduduk 2010 (Badan Pusat Statisik: Jakarta, 2010). 
pada 9 September 2001, menjadi semacam pemicu baru hubungan yang cenderung negatif antara media barat dengan Islam dan muslim.

Kai Hafez telah mengumpul beberapa gejala yang memperkeruh distorsi imej yang mendukung adanya dikotomi konsep yang berlawanan: Western "media-Islam" dan Islamic "Media-West". ${ }^{32}$ Kasuskasus yang dinilai meruncingkan hubungan itu di antaranya Krisis Terusan Suez 1955/1956, Perang Arab-Israel 1967 dan 1973, krisis minyak 1973/1974, Revolusi Iran 1979, kasus Salman Rusdhie 1989, krisis Aljazair, Perang Teluk 1991, dan hancurnya WTC.

Bagi Yusef J. Progler yang menyorot kebijakan AS dan penggambaran imej Islam, AS yang mengklaim diri sebagai negara adidaya tunggal pasca Perang Dingin dengan Uni Soviet, dianggap telah menemukan "American policy makers need an enemy."33 Meskipun kalah di Vietnam, Afghanistan dan Irak, kekuatan Amerika tetaplah kekuatan untuk berperang, baik dalam skala kata-kata dan tindakan. Dan militernya adalah salah satu industri yang tetap terus tumbuh.

Adalah menarik untuk mengutip kalimat Edward Said saat menanggapi "perhatian" yang begitu kuat dari tidak hanya media tapi juga masyarakat Barat terhadap Islam.

"Istilah 'Islam' seperti yang sering digunakan sekarang, sekilas seperti sebuah hal sederhana, tapi pada kenyataannya merupakan bagian fiksi, bagian label ideologis, bagian penunjukan minimal dari sebuah agama yang disebut Islam. Tidak ada cara signifikan yang cukup nyata kalau telah terjadi korespondensi langsung antara 'Islam' yang digunakan dalam Dunia Barat dengan variasi kehidupan yang sangat besar yang sedang terjadi di dalam dunia Islam, yang sekarang

${ }^{32}$ Lihat Kai Hafez, "The West and Islam in the Mass Media: Cornerstones for a New International Culture of Communication in the 21st Century," (Makalah, Zentrum fur Europaische Integrationforschung Discussion Paper C 61, 2000), sumber: http://aei.pitt.edu/181/ diakses 7 September 2016.

${ }^{33}$ Yusef J. Progler, "Islamic Imagery and American Policy," dalam Syed Farid Alatas (Ed.), Covering Islam: Challenges \& Opportunities for Media in the Global Village (Singapore: Centre for Research on Islamic and Malay Affairs, 2005). hh. 53-88, sumber: $h t t p / / w w w . k a s . d e / w f / d o c / k a s \_7863-1522-2-30 . p d f ? 090211042544$ diakses 6 September 2016 
populasinya telah mencapai 800 juta orang (sekarang sekitar 1,3 miliar), (menempati) jutaan mil persegi wilayah di Afrika dan Asia, puluhan kelompok masyarakat, negara, sejarah, geografi, kebudayaan. Di sisi lain, 'Islam' adalah suatu berita-berita yang berciri traumatis di Barat... Selama beberapa tahun terakhir, terutama karena peristiwa di Iran menarik perhatian Eropa dan Amerika begitu kuat, media kemudian membahas pada Islam: mereka menggambarkannya, memberi karakteristik terhadapnya, dianalisis, diberikan kursus singkat padanya dan konsekuensinya telah membuat diri mereka 'sudah tahu'". 34

\section{E. Kebebasan Pers dan Politik Islam di Sumut}

\section{Pers Islam dan Basis Sosiologis Agama}

Pers Islam dapat dilihat pada tiga hal yaitu 1) Pers yang didirikan muslim ataupun kelompok Islam; 2) Pers yang diisi oleh praktisi jurnalistik muslim; dan 3) Pers yang menyuarakan kepentingan Islam.

Bila poin pertama merujuk langsung pada media massa yang khusus didirikan untuk menyuarakan Islam, maka pada poin 2 dan 3 , media massa yang dimaksud lebih bersifat umum dan ketika didirikan memang tidak dimaksudkan secara spesifik menggolongkan diri sebagai pers Islam. Karena itu, eksistensi pers Islam dimaksudkan pada dua hal yaitu sebagai objek faktual dan sebagai nilai. Dengan demikian, mengatakan pers Islam sama sekali tidak eksis, akan bertentangan dengan fakta yang telah terjadi. Dalam hal ini, maka bila pers Islam ditujukan pada bentuk eksistensi objeknya, sementara yang lain yaitu sebagai "nilai", maka dalam kajian ini dia disebut pers Islami.

Sebagai catatan pada poin ke-2, walaupun media massa itu diisi oleh praktisi jurnalistik muslim namun belum tentu dia menyiarkan kepentingan Islam. Kepentingan Islam ini pun mesti dikaji lebih jauh dengan menggarisbawahi apakah informasi yang disiarkan itu masuk

34 Edward Said, Covering Islam (Vintage: London, 1997), h.1-li. Tanda kurung dalam kutipan ini dibuat oleh penulis. 


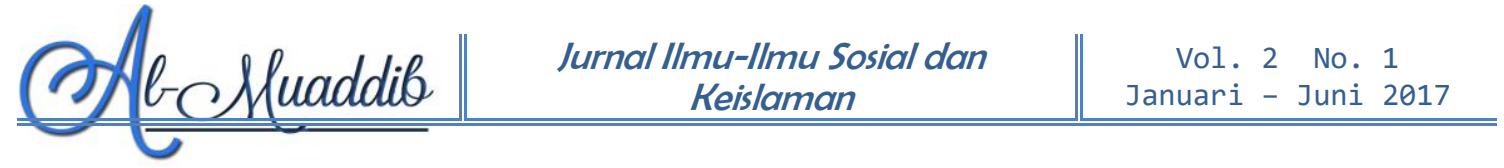

dalam kategori positif (membela), negatif (memojokkan) atau netral. Ini dengan perhitungan bahwa penyiaran peristiwa yang berkaitan dengan Islam tanpa tendesi apa-apa (apakah negatif atau positif), juga tergambar dalam pemberitaan media massa. Artinya, informasi yang disampaikan memang hanya sekedar informasi. Ini misalnya yang terjadi ketika peristiwa-peristiwa ritual keislaman, tata cara ibadah dan lain sebagainya yang bersifat rutinitas, berseliweran di media massa, baik pers Islam, islami maupun pers umum.

Dibukanya keran kebebasan untuk menyiarkan "apa saja", sebenarnya menjadi pintu gerbang bagi aktivis dari kelompok manapun untuk menyiarkan pemikiran, kampanye, ataupun propagandanya mereka. Dan itu, termasuk bagi aktivis Islam. Dengan demikian, media massa sepanjang kurun waktu penelitian ini, 1998-2011, telah berubah menjadi lahan pertarungan ideologis bagi seluruh aliran. Tapi apakah benar para aktivis Islam memanfaatkan itu?

Untuk membahasnya, kajian ini menyinggung istilah yang umum dipakai yaitu media mainstream. Istilah ini merujuk pada media massamedia massa besar (oplah, jaringan, SDM, infrastruktur) yang sering diklaim sebagai rujukan (referensi informasi) dan dapat memengaruhi wacana informasi di masyarakat. Tidak sekedar itu, namun juga dianggap mampu memengaruhi kebijakan dan keputusan politik kekuasaan. Di Sumatera Utara, beberapa media yang dianggap sebagai mainstream adalah Waspada, Analisa (terbit sejak 1972, kini juga mengakuisisi harian MedanBisnis, Sinar Indonesia Baru (terbit sejak 1970), Medan Pos dan Mimbar Umum. Selain lima besar koran di atas, surat kabar yang berafiliasi ke grup-grup media di luar Sumut, juga dapat dimasukkan di sini, seperti KoranSindo (Grup MNC, terbit di Medan pada 2005), Sumut Pos (Grup Jawa Pos, terbit sejak Oktober 2001, dulu bernama Radar Medan terbit 1 Januari 2000-30 September 2001), dan Tribun Medan (Grup Kompas, terbit sejak 2009). 


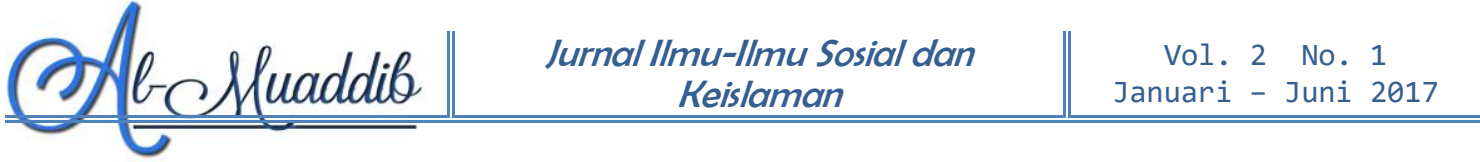

Komposisi yang semula diikuti adalah pemilahan ketiga media besar di Sumut dalam bentuk basis sosiologis. Waspada ditandai berbasis muslim, Analisa berbasis kalangan Tionghoa Budha-HinduKonghucu dan SIB yang mengandalkan massa Kristen Protestan dan Katolik yang disebutkan beririsan dengan basis massa Huria Kristen Batak Protestan (HKBP). Namun, tipologi ini agaknya hingga kini masih sekedar asumsi umum yang belum dapat dibuktikan secara faktual. Apalagi, ada pertimbangan bahwa satu pelanggan (apakah perorangan ataupun lembaga) juga berlangganan koran yang lain.

Selain itu, bila diikuti dengan komposisi penduduk di Sumut yang sejak 1980 umat Islam sebagai mayoritas dengan persentase lebih dari 60\% (pada 1980 sebesar 61,38\% dan 2010 mencapai 66,08\%), maka komposisi ini dari segi segmentasi bisnis media menjadikan umat Islam sebagai pasar terbesar dari media. Karena itu, tidaklah mengherankan bila pemilahan umat Islam sebagai pasar lebih dimungkinkan dari segi profit-oriented daripada segi ideologis. Karena itu, bersinggungan langsung secara negatif dengan umat Islam, akan sangat tidak menguntungkan bagi bisnis media. Ini tidak hanya berlaku bagi koran di Medan, tapi juga koran Jakarta yang beredar di Sumut.

Pada era industrialisasi dan kapitalisasi media, maka hubungan media-negara-agama, lebih dikarenakan kepentingan pragmatisme sesaat, hubungan saling memanfaatkan untuk untung-rugi, bukan hubungan yang berdasarkan kepentingan esensial dan pinsipil. Peristiwa-peristiwa politik yang dikabarkan media, hubungan bisnis yang terjadi antara kandidat politik dengan media, media dan negara (dalam bentuk iklan maupun pemesanan pembelian surat kabar), dan lain sebagainya, terkadang hanya membuat agama menjadi sebuah jualan politik untuk mendapat, mengukuhkan, mempertahankan, hingga melanjutkan kekuasaan politik. Padahal, media sebenarnya bisa 
memberi tawaran baru terhadap persoalan politik Islam, paling tidak untuk meminimalisir korelasi negatif antara negara dan Islam.

Terkait itu, perlu juga disampaikan di sini, selain media-media yang berafilisasi pada parpol Islam di Pemilu 1955 yang sudah disebut dalam uraian-uraian sebelumnya, tokoh-tokoh Islam sejak sebelum Indonesia merdeka, sebenarnya sudah mengambil jalur media untuk menyebarkan ide, pemikiran, peristiwa-peristiwa keislaman, termasuk politik.

\section{Tabel 2}

Media Terbitan Organisasi Keislaman dan Tokoh-tokoh Islam Kurun 1910-1966

\begin{tabular}{|c|c|}
\hline ORGANISASI/TOKOH & NAMA MEDIA \\
\hline Muhammadiyah & $\begin{array}{l}\text { Soeara Muhammadijah (1955), Penyiar Islam, Pancaran Amal, } \\
\text { Almanak Muhammadiyah, Suara Aisyiyah, Mertju Suar }\end{array}$ \\
\hline Persis & $\begin{array}{l}\text { Pembela Islam (1929), Al-Fatwa (1931), Al-Lissan (1935), At-Taqwa } \\
\text { (1937), Al-Hikam (1939), Aliran Islam (1948), Risalah (1962) }\end{array}$ \\
\hline Jami'atul Al-Washliyah & $\begin{array}{l}\text { Medan Islam (1933), Raudhatul Muta'allimin (1937), Dewan Islam } \\
\text { (1938) }\end{array}$ \\
\hline NU & Berita NU, Duta Masyarakat \\
\hline Al-Ittihadiyah & Al-Hidayah \\
\hline Syarikat Ilmu & Al-Munir (1911-1915). Terbit di Padang \\
\hline Sumatra Thawalib & Al-Munir Al-Manar (1918-1924), terbit di Padang Panjang \\
\hline Sain al-Maliki & Dunia Akhirat (1923-1925), terbit di Bukit Tinggi \\
\hline $\begin{array}{l}\text { Syekh Haji Abbas Padang } \\
\text { Japang }\end{array}$ & Al-Imam (Payakumbuh) \\
\hline Pelajar Islam Indonesia (PII) & Islam Bergerak \\
\hline Surabaya & Al-Jihad, Al-Islam \\
\hline Peranakan Arab Indonesia & Aliran Baru \\
\hline $\begin{array}{l}\text { Abdul Wahid } \\
\text { KH Abdul Madjid Abdullah }\end{array}$ & Suluh Islam (Medan) \\
\hline HR Rasuna Said & Menara Putri (Medan) \\
\hline H Bakri, Bakhtiar Yunus & Sinar (Medan) \\
\hline $\begin{array}{l}\text { Hamka, } \\
\text { Mohammad Yunan } \\
\text { Nasution }\end{array}$ & Pedoman Masyarakat (Medan) \\
\hline Zainal Abidin Ahmad & Panji Islam (Medan) \\
\hline $\begin{array}{l}\text { KH Fakih Usman, Hamka, } \\
\text { Yusuf Abdullah Puar }\end{array}$ & Panji Masyarakat (1959) \\
\hline Mas Mansoer 35 & Suara Santri \\
\hline Hamka & Al-Basyir \\
\hline$n / a$ & $\begin{array}{l}\text { 1. Terbit di Padang dan beberapa kota di Sumatera Barat): Medan } \\
\text { Rakyat, Matahari Islam, Tafsir Quran, Al-bayan, Al-Itqan } \\
\text { 2. Bandung: Pembangkit, Al-Hidayah, Aliran Muda } \\
\text { Terbit di Bandung } \\
\text { 3. Samarinda: Persatoean }\end{array}$ \\
\hline
\end{tabular}

Sumber: Heri Ruslan ${ }^{36}$ dan berbagai sumber

35 Ketua PP Muhammadiyah (1936-1942) 


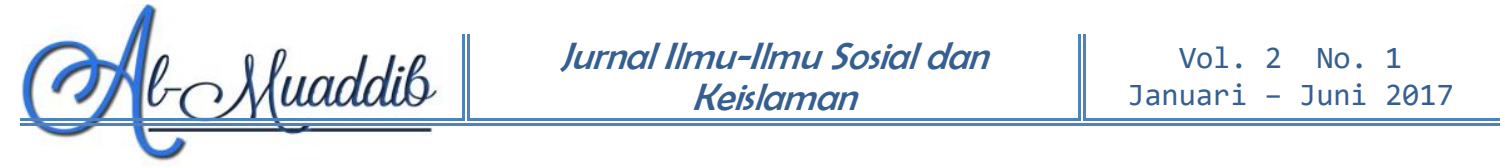

Organisasi keislaman bukan tidak serius soal media, namun cenderung tidak menjadikan jurnalistik sebagai sebuah program strategi dakwah. Lain halnya dengan penyiapan kader (kaderisasi) untuk masuk ke partai-partai politik. Karena itu pula, bila asupan jurnalis Islam di media-media umum yang lebih ideologis, kurang dibarengi dengan pemahaman Islam yang kukuh dan mendalam, namun lebih umum dan sekuler. Bahkan, dari wawancara informal yang dilakukan terhadap sejumlah jurnalis muda, menyebutkan bahwa konsepsi perjuangan Islam lewat media justru adalah hal yang tidak terlalu akrab alias asing. Itulah makanya, pergerakan politik Islam di tubuh media, kurang lebih hanya bersifat sporadis dan tidak terstruktur.

\section{Dinamika dan Output Politik Islam}

Parpol Islam ${ }^{37}$ atau partai yang berbasis dukungan umat Islam pasca 1998 menuju Pemilu 1999, tumbuh massif. Itu termasuk partai yang didirikan secara langsung maupun tidak langsung oleh organisasi Islam terbesar (NU dan Muhammadiyah) yaitu Partai Kebangkitan Bangsa dan Partai Amanat Nasional. Namun, pemenang pemilu 1999 justru adalah partai beraliran nasionalis, PDI Perjuangan. Meski demikian, tampilnya Abdurrahman Wahid yang merupakan Ketua Pengurus Besar NU sebagai Presiden dalam pemilihan di MPR yang dipimpin oleh Amien Rais (mantan Ketua PP Muhammadiyah) juga dianggap sebagai kemenangan faksi Islam.

Setelah Abdurrahman Wahid lengser, terutama di masa Megawati Soekarnoputri (2001-2004) dan Susilo Bambang Yudhoyono (20042009, 2009-2014), masyarakat Islam di Indonesia dihadapkan pada stigma "terorisme". Faktor kebijakan "war on terrorism" yang dikumandangkan AS setelah hancurnya WTC dan Pentagon,

${ }^{36}$ Heri Ruslan, Hikayat Media Massa Islam di Nusantara, (2012) sumber: http://www.republika.co.id/berita/dunia-islam/khazanah/12/04/10/m297o9hikayat-media-massa-islam-di-nusantara diakses 20 September 2016.

${ }^{37}$ Partai Persatuan Pembangunan (PPP), Partai Syarikat Islam Indonesia (PSII), Partai Umat Islam (PUI), Partai Masyumi Baru, Partai Bulan Bintang (PBB), Partai Keadilan (PK), Partai Nahdhatul Ummat (PNU), dan lain sebagainya 


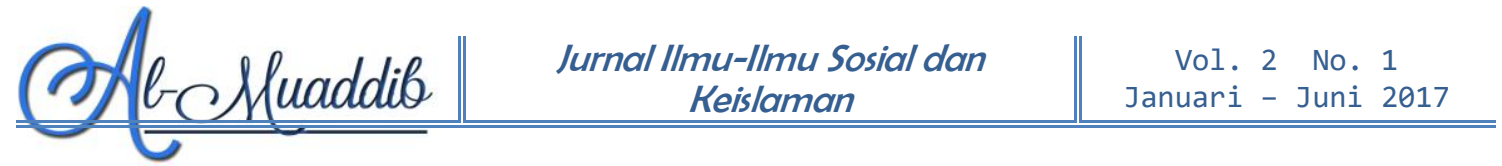

mengemuka jelas. Jangan lupa, serangkaian peledakan bom terjadi di Indonesia sebelum peristiwa ini yaitu kurun April 1999-Agustus 2001 dan periode September 2001-Juli 2009. Pemerintah yang sebelumnya tidak mempunyai aturan khusus soal terorisme, mengeluarkan Peraturan Pemerintah Pengganti Undang-undang (Perppu) Nomor 1 Tahun 2002 tentang Pemberantasan Tindak Pidana Terorisme pada 18 Oktober 2002. Keluarnya Perppu itu diikuti dengan dua instruksi presiden (inpres) soal penanganan terorisme yaitu Inpres No.4 Tahun 2002 dan Inpres No.5 Tahun 2002. Perppu itu menjadi UU No. 15 Tahun 2003 tentang Tindak Pidana Kejahatan Terorisme pada 4 April 2003.

Stigma lain yang dikenakan pada Islam adalah pada kata "jihad" yang dimasukkan dalam kamar yang sama dengan kata "teror". Label itu kemudian melekat dan tersebar luas ke masyarakat, salah satunya adalah karena media yang juga meneruskan statemen-statemen resmi dari kekuasaan pasca reformasi. Karena itu pula, fungsi integratif yang diharapkan dari media, tentu saja tidak bisa diharapkan dari kelompok media sekuler yang berhasil menguasai wacana.

\section{Diagram 2}

\section{Komposisi DPRD Sumut Periode 1999-2004 dan 2004-2009}
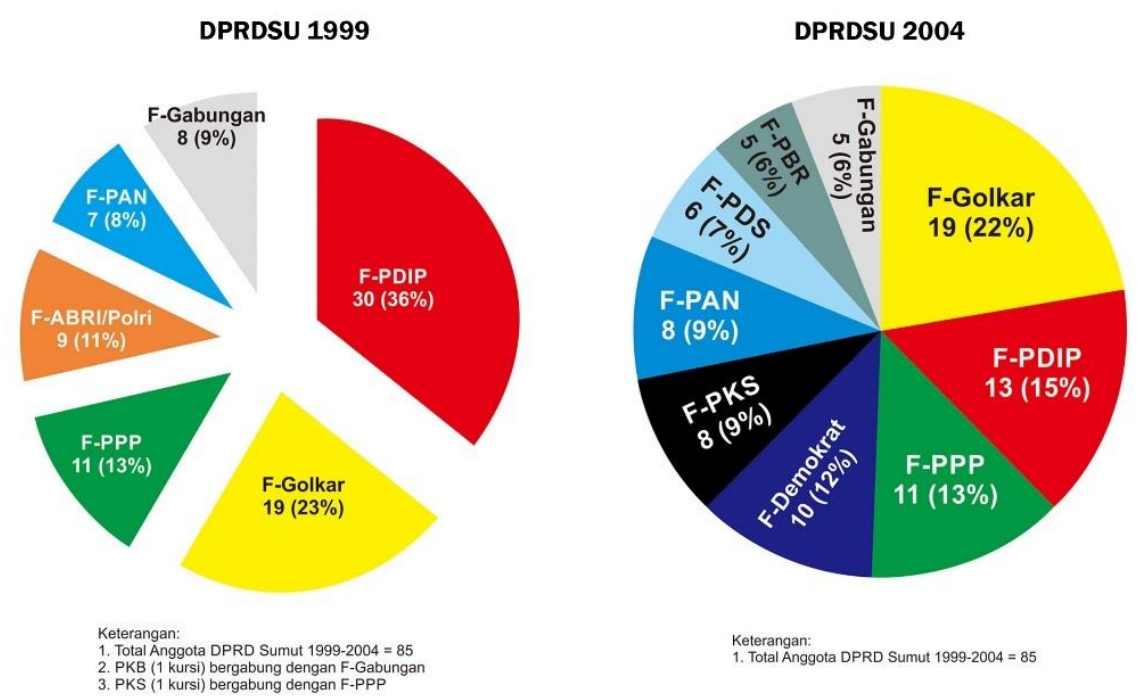

Sumber: diolah dari KPU 1999-2004 


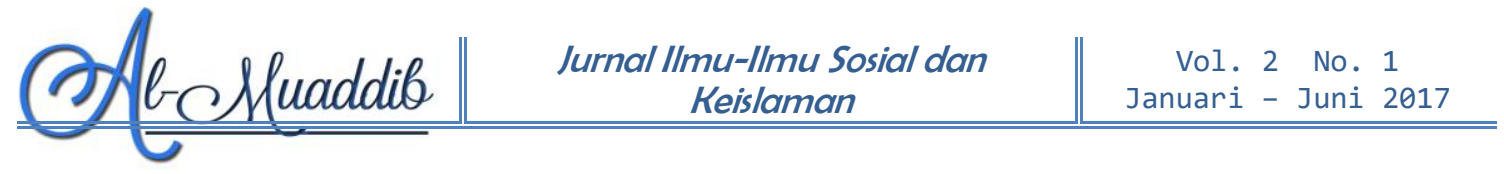

Data menunjukkan, pasca Pemilu 1999 ini, dinamika politik Islam (misalnya pilkada dan pemilu legislatif) di tingkat lokal juga kurang menggembirakan. Ruang parlemen telah dikuasai PDI Perjuangan dan Golkar, yang beraliran nasionalis kekaryaan. Seperti juga konstelasi di tingkat nasional, fraksi PPP berdiri sendiri, tidak bersama dengan partai yang berbasis massa tradisional Islam seperti PKB dan PAN. PKB malah bergabung dengan F-Gabungan, sementara PKS memilih bergabung dengan F-PAN.

Bandingkan pula dengan pertarungan politik kursi Dewan Perwakilan Daerah (DPD) pada Pemilu 2004, yang memerlihatkan konsolidasi organisasi Islam di Sumut. Calon bernama Abdul Halim Harahap yang merupakan pimpinan Jam'iyatul Al-Washliyah Sumut mendapatkan dukungan dari Pimpinan Wilayah Muhammadiyah Sumut dan organisasi keislaman lainnya. Konsekuensinya, Perolehan suara Abdul Halim Harahap sangat besar, 810.232 atau 16\% dari total suara. Perolehan suara ini merupakan yang terbesar dalam seluruh Pemilu DPD yang berlangsung hingga kajian ini ditulis.

\section{Diagram 3 \\ Komposisi DPD Asal Sumut Periode 2004-2009}

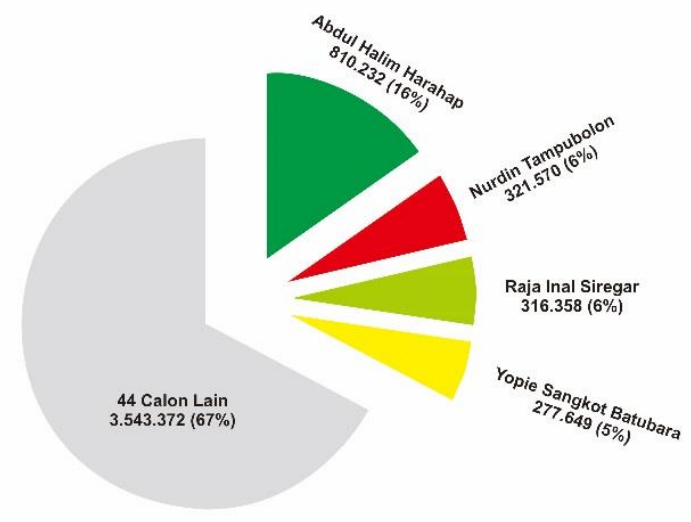

Sumber: KPU Sumut 2004

Bandingkan hasil Pemilu DPD 2004 di atas, dengan komposisi DPRD Sumut periode 2004-2009 pasca Pemilu 2004. Komposisi ini 
pada dasarnya memerlihatkan hal yang cukup signifikan bagi kekuatan politik Islam di Sumut, dengan berhasil menyusun hingga empat fraksi: F-PPP (13\%), F-PKS (9\%), F-PBR (6\%) dan F-PAN (9\%), atau total 32 kursi $(37,6 \%)$. Di sisi lain, partai berlandaskan pemilih Kristen seperti Partai Damai Sejahtera (PDS), juga mampu meraih hasil signifikan dan berhasil membentuk satu fraksi. Sementara itu, dari 29 anggota DPR asal Sumut, PPP, PKS, PAN dan PBR mampu mengirim 11 utusan.

Namun, konsolidasi pada Pemilu 2004 itu, tidak terlihat di Pemilu 2009. Calon non-muslim berhasil meletakkan dua calonnya (bahkan meraih suara terbanyak 1 dan 2) sebagai anggota terpilih DPD 2009-2014 (Rudolf M. Pardede dan Parlindungan Purba), setelah sebelumnya hanya berhasil mengirim Nurdin M. Tampubolon ke Jakarta. Hal ini menguatkan argumentasi bahwa kelompok nonmuslim lebih solid dalam mengkonsolidasikan kekuatan dan kepentingannya.

\section{Diagram 4 \\ Perbandingan Komposisi DPR Asal Sumut dan DPD Periode 2009- 2014}
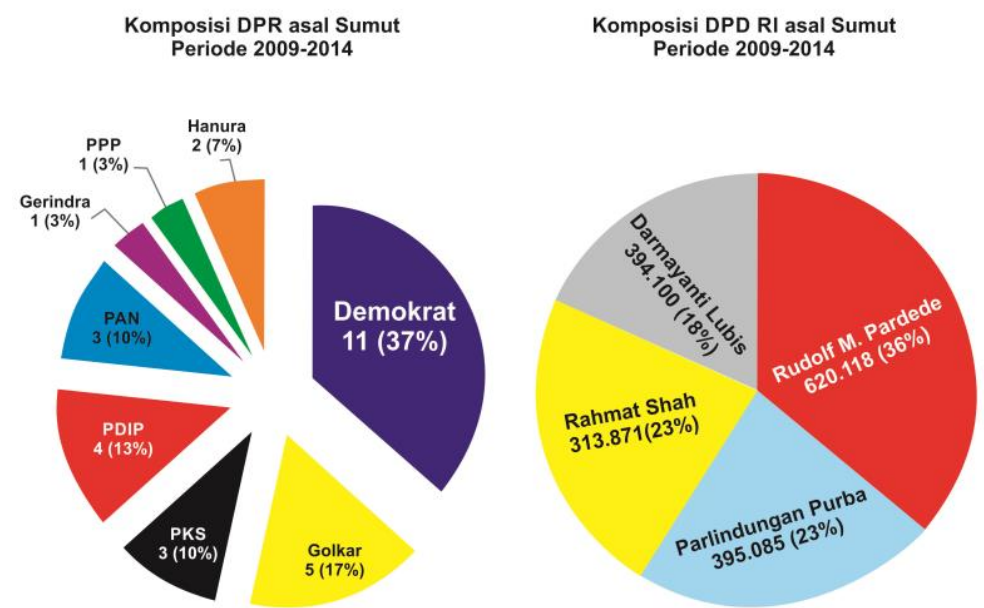

Sumber: KPU Sumut 2009 


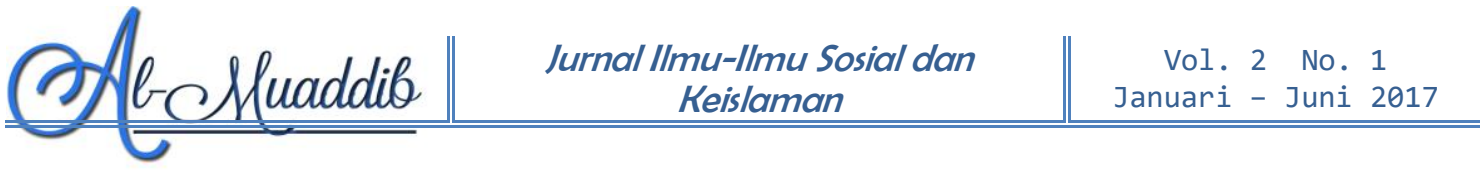

Komposisi DPRD Sumut periode 2009-2014 juga tidak memerlihatkan dominasi kekuatan politik Islam. Pertambahan kursi hanya diperoleh PKS, sementara PPP, PBR dan PAN menurun. Di sisi lain, di samping PDS ada pula F-PPRN (Partai Peduli Rakyat Nasional) yang diisi oleh mayoritas non-muslim. Di lain pihak, hanya PPP, PKS dan PAN saja yang bisa mengirimkan wakilnya menjadi anggota DPR RI asal Sumut periode 2009-2014.

\section{Diagram 5. Komposisi DPRD Sumut Periode 2009-2014}

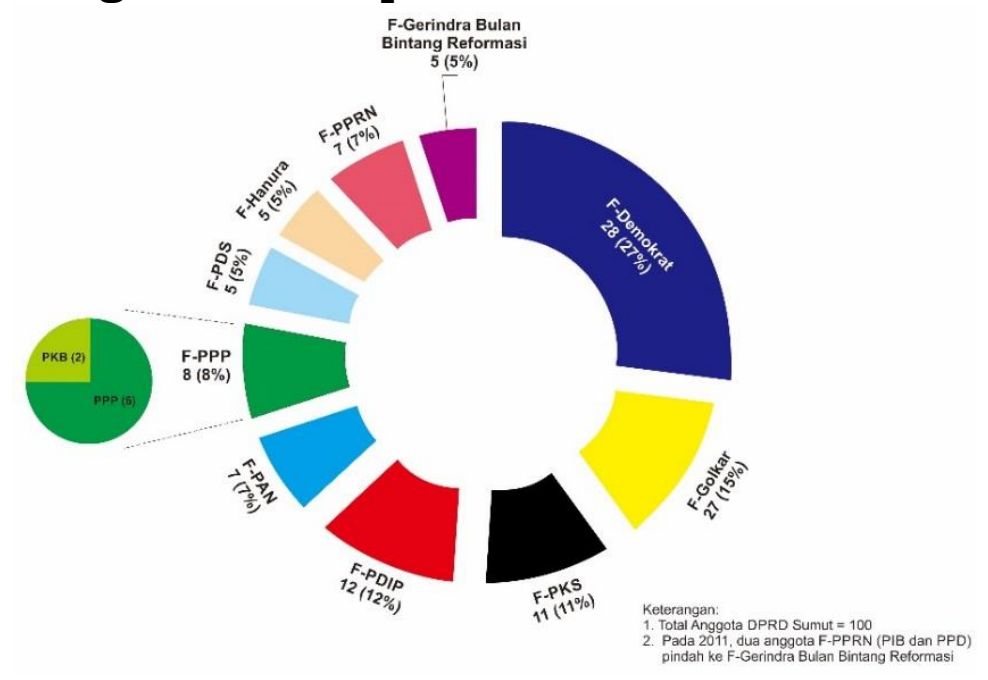

sumber: KPU Sumut 2009

Apa yang tersaji dari uraian di atas, dapat diinterpretasikan bahwa solidaritas dan soliditas dalam menjembatani kepentingan untuk masuk dalam ranah kekuasaan, tidak mengalami konsistensi yang kukuh dan bersifat temporer (sementara). Ketiadaan kinerja yang terstruktur, sistematis dan stabil/konstan antara berbagai kekuatan politik umat Islam, seperti yang telah disinggung sebelumnya, mendapatkan argumentasinya di sini.

Karena itu pula, reformasi 1998 yang membuka keran bagi kencangnya aktivis Islam dalam politik praktis, ternyata tidak membuat banyak keuntungan bagi kepentingan umat Islam secara keseluruhan, apalagi bila dikaitkan dengan revivalisme (kebangkitan) Islam. Masuknya aktivis Islam dalam struktur partai yang non-Islam, justru dinilai malah tidak akan mampu untuk berbuat banyak bagi 


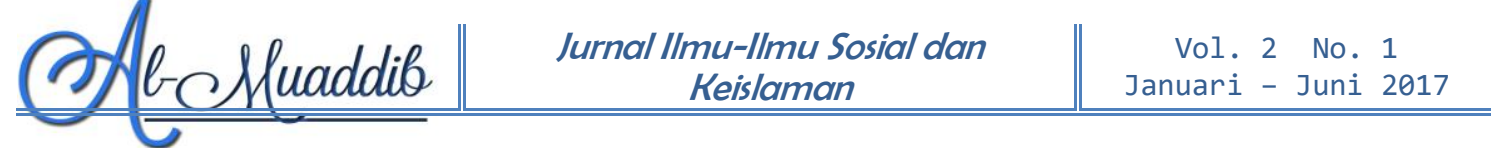

kepentingan Islam. Hal tersebut tentu saja berpengaruh pada output parlemen yaitu budgetting, pengawasan, dan legislasi, yang pada kenyataannya tidak terlalu menggembirakan bagi kepentingan Islam. Meskipun, gerakan politik Islam memang tidak bisa direduksi pada aktivitas politik praktis di dataran parlemen.

\section{Tabel 3 Pertumbuhan Rumah Ibadah di Indonesia 1997-2004 dan Jumlah Pemeluk Agama Tahun 2010}

\begin{tabular}{|l|l|l|l|c|c|c|}
\hline \multirow{2}{*}{ AGAMA } & \multicolumn{4}{|c|}{ RUMAH IBADAH } & PEMELUK AGAMA 2010 \\
\cline { 2 - 7 } & $\begin{array}{l}\text { RUMAH } \\
\text { IBADAH }\end{array}$ & $\mathbf{1 9 9 7}$ & $\mathbf{2 0 0 4}$ & PERSENTASE & PEMELUK & PERSENTASE \\
\hline ISLAM & Masjid & 392.044 & 643.843 & 64 & 207.176 .162 & 87,18 \\
\hline PROTESTAN & Gereja & 18.977 & 43.909 & 131 & 16.528 .513 & 6,96 \\
\hline KATOLIK & Gereja & 4.934 & 12.473 & 153 & 6.907 .873 & 2,91 \\
\hline PURA & Pura & 4.247 & 24.231 & 474 & 4.012 .116 & 1,69 \\
\hline BUDHA & Vihara & 1.523 & 7.129 & 368 & 1.703 .254 & 0,72 \\
\hline KONGHUCU & Kelenteng & n/a & n/a & - & 117.091 & 0,05 \\
\hline
\end{tabular}

Sumber: Diolah dari data Kemenag 201038, SP $2010^{39}$

Seperti yang sudah disinggung sebelumnya, ketidaksolidan kekuatan politik Islam ini berbanding terbalik dengan progres kekuatan politik dan agregasi kepentingan kelompok non-muslim pasca 1998. Di antara contoh yang dapat dikemukan adalah pertambahan jumlah ibadah di Indonesia.

Lonjakan kuantitasi rumah ibadah non-muslim secara nasional ini mulanya memang cukup mengagetkan karena pertumbuhan rumah ibadah Islam, dalam hal ini yang disebutkan adalah masjid, hanya 64\%. Sedangkan rumah ibadah lain angka pertumbuhannya di atas $100 \%$. Pertumbuhan yang fantastis dapat terlihat pada Vihara Budha (368\%) dan Pura (kuil) Hindu yang mencapai 474\%.

${ }^{38}$ Tabel diperoleh dari statemen Kepala Pusat Kerukunan Beragama Kemenag RI, Abdul Fatah, pada Republika Ahad, 3 Juni 2012, sumber: http://www.republika.co.id/berita/dunia-islam/islam-nusantara/12/06/03/m51lw4pertumbuhan-masjid-di-indonesia-rendah, diakses 22 Oktober 2016.

${ }^{39}$ Badan Pusat Statistik, Kewarganegaraan, Suku Bangsa, Agama dan Bahasa Sehari-hari Penduduk Indonesia: Hasil Sensus Penduduk 2010 (Badan Pusat Statisik: Jakarta, 2010). 
Kondisi berbeda tampak di Sumut. Mari lihat jumlah rumah ibadah masing-masing agama di Sumut seperti tertera dalam tabel di bawah ini.

\section{Tabel 4}

\section{Pertumbuhan Rumah Ibadah di Sumatera Utara}

Periode 1998-2010

\begin{tabular}{|c|c|c|c|c|c|c|}
\hline \multirow{2}{*}{ TAHUN } & \multirow{2}{*}{ MASJID } & \multicolumn{2}{|c|}{ GEREJA } & \multirow{2}{*}{ KUIL } & \multirow{2}{*}{$\begin{array}{l}\text { VIHAR } \\
\text { A }\end{array}$} & \multirow{2}{*}{ KELENTENG } \\
\hline & & PROTESTAN & KATOLIK & & & \\
\hline 1998 & 8.685 & 9.404 & 1.684 & 42 & 153 & - \\
\hline 1999 & 8.688 & 9.404 & 1.693 & 47 & 153 & - \\
\hline 2000 & 8.049 & 8.522 & 1.752 & 118 & 310 & - \\
\hline 2001 & 7.822 & 10.148 & 2.061 & 50 & 505 & - \\
\hline 2002 & - & - & - & - & - & - \\
\hline 2003 & 7.319 & 9.912 & 2.064 & 215 & 247 & - \\
\hline 2004 & - & - & - & - & - & - \\
\hline 2005 & 8.328 & 9.812 & 2.055 & 52 & 157 & - \\
\hline 2006 & 9.199 & 9.812 & 2.092 & 58 & 206 & 71 \\
\hline 2007 & 9.199 & 10.277 & 2.134 & 367 & 77 & - \\
\hline 2008 & 9.201 & 10.148 & 2.098 & 72 & 367 & 78 \\
\hline 2009 & 9.290 & 11.989 & 2.164 & 65 & 367 & 78 \\
\hline 2010 & 9.011 & 9.514 & 1.814 & 710 & 1.234 & 65 \\
\hline
\end{tabular}

Sumber: Diolah dari data BPS Sumut 1998-2010

Data di atas menunjukkan jumlah rumah ibadah umat Islam lebih sedikit daripada umat non-muslim, terutama Kristen Protestan. Angka itu akan jauh lebih sedikit bila rumah ibadah Kristen Protestan dan Katolik digabungkan. Data ini akan lebih menarik ketika jumlah pemeluk agama di Sumut dibandingkan dengan jumlah rumah ibadahnya. Mari ambil perbandingan di tahun 2010.

Tabel 5

Rasio Pemeluk Agama dan Rumah Ibadah di Sumut 2010

\begin{tabular}{|l|l|l|l|l|}
\hline AGAMA & \multicolumn{2}{|l|}{ RUMAH IBADAH 2010 } & $\begin{array}{c}\text { PEMELUK } \\
\mathbf{2 0 1 0}\end{array}$ & RASIO \\
\hline ISLAM & Masjid & 9.011 & 8.579 .830 & $1: 952$ \\
\hline PROTESTAN & Gereja & 9.514 & 3.509 .700 & $1: 368$ \\
\hline KATOLIK & Gereja & 1.814 & 516.037 & $1: 284$ \\
\hline HINDU & Pura & 710 & 14.644 & $1: 20$ \\
\hline BUDHA & Vihara & 1.234 & 303.548 & $1: 245$ \\
\hline KONGHUCU & Kelenteng & 65 & 984 & $1: 15$ \\
\hline
\end{tabular}




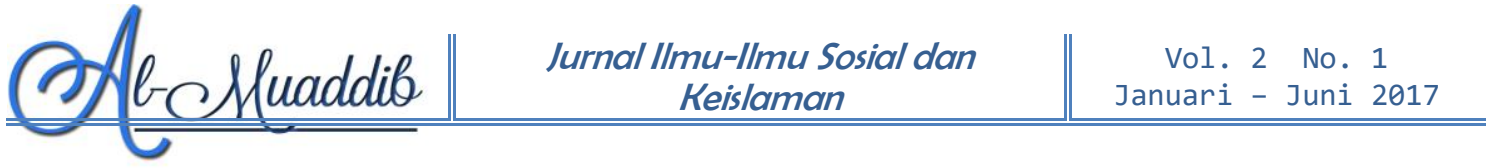

Dalam data itu tergambar jelas bila di 2010, umat Islam di Sumut yang jumlahnya mayoritas $(66,08 \%)$ mengalami rasio yang terendah: sebuah masjid rata-rata harus melayani 952 umat Islam (1:952). Rasio itu sangat jauh bila dibandingkan denga umat Kristen Katolik dan Protestan, dan terutama dengan agama baru, Konghucu. Bandingkan pula hasil ini dengan rasio rata-rata nasional untuk umat Islam yang 1:322, maka perbandingannya sangat jauh. Lihat pula rasio umat non-muslim, misalnya Kristen Protestan dan Katolik, yang tidak berbeda jauh dengan rasio rata-rata nasional. Dari sisi ini, maka pekerjaan rumah bagi kekuatan politik Islam di Sumut, nyatanya jauh lebih besar dari rata-rata nasional.

Memang, untuk menarik sebuah interpretasi dari data-data di atas, maka harus diperhitungkan pula nilai rata-rata persebaran di seluruh kawasan. Faktanya, di Sumut sendiri memang terbagi pada kawasan yang mayoritas muslim dan non-muslim terutama Kristen di kawasan Tapanuli Utara, Tapanuli Tengah, Sibolga, Humbang Hasundutan, Simalungun, Siantar hingga Nias. Namun, dengan mengambil persentase mayoritas muslim di Sumut, maka nilai itu, sekali lagi, mengisyaratkan bahwa output kekuatan politik umat Islam di Sumut masih perlu banyak pertanyaan.

Belum lagi bila penelitian ini menyelidiki lebih jauh data-data alokasi anggaran APBD Sumut dan Kabupaten/Kota terhadap organisasi Islam, organisasi kemahasiswaan Islam, lembaga-lembaga pendidikan, perayaan hari besar Islam, dan lain-lain yang berkaitan dengan kepentingan umat Islam, misalnya saja perda syariah.

Karena itu, di hadapan serbuan wacana dan informasi yang tidak memihak kepada Islam secara langsung maupun tidak langsung, pilihan untuk mempunyai media massa sendiri dirasakan sebagai hal yang realistis. Namun, bukan berarti tidak mempunyai kendala. Seperti yang sudah diurai dalam bagian sebelumnya, kendala manajemen dan profesionalisme praktisi pers, masih menghadang. Selain itu, faktor 


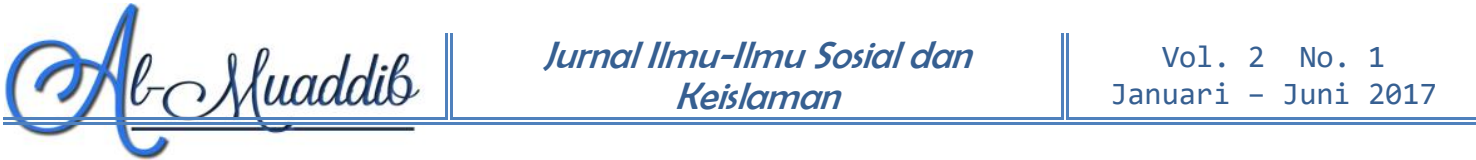

kapabilitas sumber daya jurnalis Islam dalam mengendus dan menghadapi isu-isu keislaman juga duduk dalam daftar masalah yang harus diselesaikan. Majalah-majalah Islam juga sudah lama tutup di antaranya Panji Masyarakat, Amanah, Media Dakwah, Al Muslimun, Ummat hingga Madina. Majalah Sabili yang terbit pertama pada 1992, juga dikabarkan kian terseok-seok, seperti yang terjadi dengan Suara Hidayatullah, Ummi dan Alia.

Karena itu, jalur dakwah yang dipakai selama ini yaitu dakwah dari mimbar ke mimbar, akan terlihat konvensional bila dibandingkan dengan massifnya perkembangan media massa dan new wave media. Tema-tema yang diberikan dalam model komunikasi langsung tatap muka seperti itu, menghadapi kendala yang bersifat konvensional seperti persebaran dan tak tersimpan dalam waktu yang panjang (short term). Pada dasarnya, dakwah literasi dan multimedia, yang sangat bisa diakomodir dan bahkan menjadi pekerjaan rutin dari media massa, belum dimanfaatkan secara maksimal untuk kepentingan politik Islam. Lagipula, adanya keengganan untuk membahas tema-tema politik Islam dalam pengajian-pengajian komunitas hingga masjid-masjid, kian melemahkan pandangan umat Islam terhadap kondisi riil sosial politik yang dihadapi di Sumut.

Dengan realitas politik yang begitu kecil kemungkinannya, maka seperti sudah dikatakan sebelumnya, pertarungan yang tersisa adalah mengisi struktur kekuasaan, baik di eksekutif maupun legislatif.

\section{G. Kesimpulan}

Kebebasan pers berdampak langsung maupun tidak langsung bagi dinamika politik Islam di Sumut. Dalam hal membandingkan kebebasan pers antara masa orla, orba dan reformasi, telah terjadi proses kontinum diskursus kebebasan pers disertai dinamikanya masing-masing. UU Pokok Pers No. 40 Tahun 1999 memang mengurangi kendali pemerintah terhadap pers. Namun, pelaksanaan dalam tahapan berikutnya di era industrialisasi dan kapitalisasi media, 
justru insan pers harus berhadapan dengan dirinya sendiri: pemilik modal-media dan profesionalisme. Diskursus politik Islam di media periode 1998-2011, tak terpisahkan dengan depolitisasi politik Islam di masa orba yang kemudian menentukan wacana keislaman di Sumut dan turut menyumbang melemahnya potensi kekuatan politik Islam.

Diskursus politik Islam di media merupakan gambaran definisi dan pemaknaan politik Islam di kalangan media maupun aktivis sosial politik Islam di Sumut, yang secara garis besar terbelah pada pemahaman holistik (radikal maupun moderat) dan sekuler.

Kebijakan media dan pemilik, menjadi dasar proses jurnalistik di tingkat jajaran redaksional. Ketiadaan media yang berkonsentrasi pada politik Islam, dan lebih memilih segmentasi umum-sekuler, membuat agenda politik Islam tergantung pada pertimbangan ideologis pemilik dan pilihan segmentasi pasar. Selain itu, program khusus terstruktur dan sistematis yang berkonsentrasi di bidang jurnalisme Islam di organisasi dan partai keislaman, sangat minim, sporadis, tak terjadwal, dan tidak mempunyai output tertentu soal media dan politik Islam. Sehingga, media umum yang lebih sekuler menguasai penyebaran wacana dan informasi. Padahal, media diakui sangat penting untuk kekuatan politik Islam. (*)

\section{DAFTAR PUSTAKA}

Althusser, L. Ideology and Ideological State Apparatuses, in Lenin and Philosophy and Other Esaays. London: New Left Books, 1971.

Badan Pusat Statistik. Kewarganegaraan, Suku Bangsa, Agama dan Bahasa Sehari-hari Penduduk Indonesia: Hasil Sensus Penduduk 2010. Badan Pusat Statisik: Jakarta, 2010.

Badan Pusat Statistik Provinsi Sumatera Utara. Sumatera Utara dalam Angka 2001. Medan: Badan Pusat Statistik Provinsi Sumatera Utara, 2001-2013.

- Sumatera Utara dalam Angka 2013. Medan: Badan Pusat Statistik Provinsi Sumatera Utara, 2013. 
Chadha, Kalyani dan Anandam Kavoori. "Media imperialism revisited: some findings from the Asian Case," dalam Media Culture \& Society, 2000. (https://www.researchgate.net/profile/Kalyani_Chadha/publicati on/240707871_Media_imperialism_revisited_Some_findings_from_t he_Asian_case/links/5754210208ae10d933792d39.pdf?origin=pu blication_detail diakses pada 5 September 2016).

Djankov, Simeon, et. al. "Who Owns the Media?" Journal of Law and Economics, vol. XLVI. University of Chicago, 2003.

Effendy, Bahtiar. Islam dan Negara: Transformasi Gagasan dan Praktik Politik Islam di Indonesia. Jakarta: Paramadina, 1998.

Eriyanto. Analisis Wacana, Pengantar Analisis Teks Media. Yogyakarta: LkiS, 2005.

Esposito, John L. Islam: The Straight Path. New York: Oxford University Press, 1988.

French, Mary Catherine. "Reporting Socialism: Soviet Journalism and the Journalists' Union, 1955-1966." Publicly Accessible Penn Dissertations, Pennsylvania: Penn Libraries University Pennsylvania, 2014. (http:// repository.upenn.edu/cgi/viewcontent.cgi?article $=3089 \& c 0$ ntext=edissertations pada 3 September 2016)

Gramsci, Antonio. "Quaderni del carcere," dalam Quentin Hoare dan Geoffrey Nowell Smith (ed). Selection from the Prison Notebooks. London: $\quad$ ElecBook, 1999. (http://courses.justice.eku.edu/pls330_louis/docs/gramsci prison-notebooks-vol1.pdf, diakses 2 September 2016; https://www. marxists.org/archive/gramsci/prison_notebooks/selections.htm, diakses 2 September 2016)

Hafez, Kai. "The West and Islam in the Mass Media: Cornerstones for a New International Culture of Communication in the $21 \mathrm{st}$ Century,". Makalah, Zentrum fur Europaische Integrationforschung Discussion Paper C 61, 2000. (http://aei.pitt.edu/181/ diakses 7 September 2016).

Haryanto, Ignatius. "Media Ownership and Its Implication for Journalists and Journalism in Indonesia," dalam Krishna Sen and David Hill (eds.), Politics and the New Media in 21st Century Indonesia: Decade of Democracy. New York: Routledge, 2011. 
Hill, David T. Pers di Masa Orde Baru. Jakarta: Yayasan Pustaka Obor Indonesia, 2011.

Kartosapoetro, Ishadi Soetopo. Media dan Kekuasaan: Televisi di Harihari Terakhir Presiden Soeharto. Jakarta: Penerbit Buku Kompas, 2014.

Lim, Merlyna. The League of Thirteen: Media Concentration in Indonesia. Arizona: Participatory Media Lab Arizona State University, 2012. (http://www.public.asu.edu/ mlim4/files/Lim_IndoMediaOwners hip_2012.pdf diakses 10 Maret 2013)

Manan, Abdul. Ancaman itu Datang dari Dalam: Laporan Tahunan Aliansi Jurnalis Independen 2010. Jakarta: Aliansi Jurnalis Independen, 2010.

McQuail, Denis. Teori Komunikasi Massa, Suatu Pengantar. Jakarta: Erlangga, Edisi Kedua, 1991.

Miles, Matthew B. dan A. Michael Huberman. Analisis Data Kualitatif: Buku Sumber Tentang Metode-metode Baru. Jakarta: UI Press, 1992.

Milosevic, Mira, et. al. World Press Trends 2014. Paris: WAN-IFRA, 2014.

Nasikun. Sistem Sosial Indonesia. Jakarta: Rajawali Press, 2010.

Nordenstreng, K. dan T. Varis. Television Traffic - A One Way Street? Paris: UNESCO, 1974.

Progler, Yusef J. "Islamic Imagery and American Policy," dalam Syed Farid Alatas (Ed.), Covering Islam: Challenges \& Opportunities for Media in the Global Village. Singapore: Centre for Research on Islamic and Malay Affairs, 2005. (sumber: http//www.kas.de/wf/doc/kas_7863-1522-230.pdf?090211042544 diakses 6 September 2016).

Rais, Mohammad Amien. Agenda Mendesak Bangsa, Selamatkan Indonesia! Yogyakarta: PPSK Press, 2008.

Rasyidin, Al. "Islamic Organizations in North Sumatra; The Politics of Initial Establishment and Later Development," dalam Journal of Indonesia Islam Vol $10 \quad$ No. 1 Juni 2016. (http://jiis.uinsby.ac.id/index.php/JIIs/article/view/210/164, diakses 30 Oktober 2016).

Ruslan, Heri. "Hikayat Media Massa Islam di Nusantara,". 2012. (http://www.republika.co.id/berita/duniaislam/khazanah/12/04/10/ m297o9-hikayat-media-massa-islamdi-nusantara diakses 20 September 2016). 
Said, Edward. Covering Islam. Vintage: London, 1997.

Tunstall, Jeremy. Journalist at Work. London: Constable, 1971.

\section{Referensi Situs}

http://arsip.gatra.com/2000-10-10/artikel.php?id=152 diakses 28 Oktober 2016.

http://www.un.org/en/universal-declaration-human-rights/index.html diakses 5 September 2016.

http://www.republika.co.id/berita/dunia-islam/islamnusantara/ 12/06/03/m51lw4-pertumbuhan-masjid-di-indonesiarendah, diakses 22 Oktober 2016. 